\title{
ЗАГАЛЬНІ ОСОБЛИВОСТІ ДИНАМІКИ ПРИЧИН СМЕРТІ СЕРЕД РІЗНИХ ВЕРСТВ ДОРОСЛОГО НАСЕЛЕННЯ ЛЬВІВСЬКОЇ ОБЛАСТІ
}

\author{
${ }^{1}$ ДУ «Український інститут стратегічних досліджень МОЗ України», м. Київ \\ 2 Львівський національний медичний університет ім. Данила Галицького, Україна
}

\begin{abstract}
Мета: проаналізувати втрати дорослого населення Львівської області.
Матеріали і методи. У ході дослідження використані бібліосемантичний та статистичний методи. Первинним матеріалом були дані офіційної статистики - форми статистичного обліку за період 2008-2012 років.

Результати. У структурі померлих Львівської області в усі роки спостереження частка осіб працездатного віку чоловічої статі у чотири рази перевищує таку жіночої з практично однаковим темпом зменшення; очікувано переважає доля осіб старше працездатного віку. Структура причин смерті сільського та міського населення області збігалася за роки вивчення: перші три місця належали хворобам системи кровообігу, злоякісним новоутворенням, зовнішнім причинам. Основними причинами втрати осіб пенсійного віку за всі роки вивчення є хвороби системи кровообігу, злоякісні новоутворення та хвороби органів дихання.

Висновки. Встановлені відмінності в рівнях та причинах смертності різних категорій населення слід враховувати при розробці комплексних заходів зниження смертності населення.
\end{abstract}

КЛЮЧОВІ СЛОВА: смертність дорослого населення, динаміка, причини.

Для визначення стратегічних напрямів розвитку медичної галузі, спрямованої на покращення здоров'я населення, розробки тактики їх втілення, необхідний детальний аналіз стану здоров'я різних верств населення, у тому числі показників смертності, з метою виявлення як загальних змін, так і окремих причин [1-5].

Мета роботи: провести аналіз втрат дорослого населення Львівської області.

Матеріали і методи. У ході дослідження використані бібліосемантичний та статистичний методи. Первинним матеріалом були дані офіційної статистики - форми статистичного обліку № 103/o, №106/o, №106-1/o, TC-2, TC-3, PH-1, C-8, PH-2, Ф. №151/о за період 2008-2012 років.

Отримані дані оброблялися з використанням загальноприйнятих методів.

Результати дослідження та їх обговорення. Динаміку структури померлих у Львівській області за основними віковими групами та статтю наведено у табл. 1. Як бачимо, у структурі померлих за роками спостерігається ряд відмінностей. Розглянемо основні з них. Втрати чоловічого населення працездатного віку у понад чотири рази перевищують такі серед жінок того ж вікового періоду. Так, у 2012 р. цей показник становив 29,02\% і 6,67\% відповідно. Проте темпи зменшення показників, що є характерною ознакою для обох статей, майже однакові - 20,4\% серед чоловіків і $19,7 \%$ жінок.

Очікуваним є приріст померлих у старшому за працездатний віці. Інтенсивнішій він серед чоловіків (12,0\% проти 2\% серед жінок), тоді як випадків смерті серед чоловіків даної вікової ка-

(C) Ю.Б. Ященко, О.А. Семенюк, Я.Л. Гржибовський, 2014 тегорії у 1,3-1,5 разу менше, ніж серед жінок. Так, у 2012 р. цей показник становив 69,85\% проти $92,31 \%$ у жінок.

Таким чином, більш несприятлива ситуація щодо смертності спостерігається серед населення чоловічої статі працездатного віку, ніж серед жінок такого ж віку. Встановлено, що за період вивчення причини смерті та їх ранговий розподіл серед населення Львівської області (за МKX-10) залишалися незмінними i, за окремим винятком, не відрізнялися від ситуації в Україні в цілому. Як видно з таблиці 2, провідні місця у структурі причин смерті постійно посідали: хвороби системи кровообігу, злоякісні новоутворення, зовнішні причини смерті. Стійко займали свої місця протягом років інфекції та паразитарні хвороби (6), хвороби сечостатевої системи (9), хвороби кістковом'язової та сполучної тканини (10) та хвороби крові (11). Водночас за рахунок різної інтенсивності зменшення рівнів смерті, дані про які наводимо нижче, у 2012 р. 4, 5, 7, 8 місця займали хвороби органів травлення, дихання, ендокринні та нервові хвороби, тоді як у 2008 р. вони належали хворобам органів дихання, травлення, хворобам нервової системи, ендокринним хворобам відповідно. Відмінність розподілу відносно України в цілому стосувалась лише 7, 8, 9 місць, які протягом років посідали хвороби нервової, сечостатевої систем та ендокринні хвороби. Тобто у 2012 р. шість перших місць збігалися, і причини смерті розташувались у наступній послідовності: хвороби системи кровообігу, злоякісні новоутворення, зовнішні причини, хвороби органів травлення, дихання, інфекційні та паразитарні хвороби. Збігалися й два останні - хвороби кістково-м'язової та сполучної тканини (10 місце) і хвороби крові (11 місце). 
Таблиця 1. Структура померлих у Львівській області у 2008-2012 рр. за основними віковими групами та статтю (\%)

\begin{tabular}{|c|c|c|c|c|}
\hline \multirow{2}{*}{ Рік } & \multicolumn{2}{|c|}{ Чоловіки } & \multicolumn{2}{|c|}{ Жінки } \\
\cline { 2 - 5 } & працездатні & $\begin{array}{c}\text { старші } \\
\text { працездатного віку }\end{array}$ & працездатні & $\begin{array}{c}\text { старші } \\
\text { працездатного віку }\end{array}$ \\
\hline 2008 & 36,46 & 62,35 & 8,31 & 90,48 \\
\hline 2009 & 31,64 & 67,2 & 7,6 & 91,53 \\
\hline 2010 & 30,47 & 68,19 & 6,88 & 92,12 \\
\hline 2011 & 29,89 & 68,63 & 6,81 & 92,19 \\
\hline 2012 & 29,02 & 69,85 & $-19,7 \%$ & $+2,0 \%$ \\
\hline
\end{tabular}

Таблиця 2. Динаміка основних причин смерті всього населення України та Львівської області (на 100 тис. відповідного населення)

\begin{tabular}{|l|c|c|c|c|c|c|}
\hline \multirow{2}{*}{ Основна причина смерті } & \multicolumn{3}{|c|}{ Україна } & \multicolumn{3}{c|}{ Львівська область } \\
\cline { 2 - 7 } & 2008 & 2012 & Т п/3 & 2008 & 2012 & Т п/3 \\
\hline $\begin{array}{l}\text { Інфекційні та паразитарні хвороби, у т.ч. } \\
\text { туберкульоз }\end{array}$ & 37,4 & 30,6 & $-18,2$ & 26,1 & 21,0 & $-27,4$ \\
\hline Злоякісні новоутворення & 190,7 & 202,3 & $+6,0$ & 156,6 & 172,8 & $+10,3$ \\
\hline Хвороби крові & 0,7 & 0,7 & 0 & 0,7 & 0,9 & $+28,6$ \\
\hline Ендокринні хвороби, & 6,1 & 5,6 & $-8,2$ & 8,1 & 7,9 & $-2,5$ \\
\cline { 1 - 7 } у. ч. цукровий діабет & 5,4 & 4,9 & $-9,2$ & 7,6 & 7,1 & $-6,6$ \\
\hline Хвороби нервової системи & 15,8 & 12,9 & $-18,3$ & 10,0 & 6,7 & $-33,0$ \\
\hline Хвороби кровообігу & 1039,4 & 960,2 & $-7,6$ & 893,6 & 811,6 & $-9,2$ \\
\cline { 2 - 7 } у т. ч. ГХ & 1,4 & 1,6 & $+14,3$ & 2,0 & 2,0 & 0 \\
\cline { 2 - 7 } $\begin{array}{l}\text { інфаркт міокарда } \\
\text { ішемічна хвороба серця }\end{array}$ & 21,7 & 25,3 & $+16,5$ & 22,8 & 22,4 & $-17,5$ \\
\cline { 2 - 7 } інсульти & 694,0 & 654,4 & $-5,7$ & 682,8 & 597,6 & $-12,5$ \\
\cline { 2 - 7 } цереброваскулярні хвороби & 91,8 & 91,7 & $-0,1$ & 83,8 & 72,1 & $-14,0$ \\
\hline Хвороби органів дихання & 223,1 & 204,5 & $-8,3$ & 115,1 & 108,3 & $-6,0$ \\
\hline Хвороби органів травлення & 50,4 & 37,6 & $-25,3$ & 55,5 & 37,9 & $-31,7$ \\
\hline Хвороби кістково-м'язової системи & 76,2 & 61,0 & $-20,0$ & 54,7 & 42,7 & $-22,0$ \\
\hline Хвороби сечостатевої системи & 1,6 & 1,3 & $-18,7$ & 2,2 & 1,2 & $-4,5$ \\
\hline Зовнішні причини & 14,6 & 7,0 & $-52,0$ & 5,1 & 4,5 & $-11,7$ \\
\hline
\end{tabular}

Динаміка показників свідчить про зниження їх рівнів, за винятком злоякісних новоутворень та хвороб крові. Темп приросту перших більший у регіоні (10,3\%), ніж в країні $(6,0 \%)$, а хвороб крові становив 28,6\% при незмінному показнику в Україні. Інтенсивність зменшення смертності була різною в розрізі причин та територій. Суттєвою вона виявилася від зовнішніх причин (31,0\% та 34,6\% в Україні та регіоні відповідно), хвороб органів дихання $(25,3 \%$ та $31,7 \%)$, органів травлення (20,0\% та 22,0\%). Меншою мірою змінилися показники при хворобах кровообігу (7,6\% та 9,2\% відповідно), ендокринних хворобах (8,2\% та 2,5\% відповідно). Найчастішою причиною смерті від хвороб кровообігу є ішемічна хвороба серця (IXC), цереброваскулярні хвороби, інсульт. Слід зазначити, що смертність від IXC та інсультів в області зазнала більших змін, ніж в країні - на $12,5 \%$ та $14,0 \%$ проти $5,7 \%$ та 0,1\% відповідно.

Серйозним питанням при розробці заходів покращення ситуації, з огляду на відомі відмінності матеріально-технічного забезпечення, доступність медичної допомоги міському і сільському населенню, є володіння інформацією щодо причин смерті на зазначених територіях та аналіз динаміки їх змін у порівняльному аспекті. Отримані дані вказують на те, що структура причин смерті за класами хвороб в області серед сільського та міського населення ідентична усі роки, за винятком лише четвертого-п'ятого місць: четверте в першому випадку належало органам дихання, а п'яте - травленню, а в другому - навпаки. Перші три місця належали хворобам кровообігу (серед яких ідентично найпоширенішими були IXC, цереброваскулярні хвороби, інсульт), злоякісним новоутворенням та зовнішнім причинам; наступні 6-11 займали інфекційні, ендокринні хвороби, хвороби нервової, сечостатевої, кістково-м'язової систем та хвороби крові. Варто вказати на подібність розподілу серед вказаних верств населення й в цілому по Україні. Проте існує одна відмінність: в області сьоме місце посідають ендо- 
кринні хвороби, а в Україні - хвороби нервової системи, восьме розподіляється навпаки.

Слід наголосити, що за роки вивчення серед сільського населення відмічалось суттєве зростання втрат з приводу злоякісних новоутворень (14,0\%), ендокринних хвороб $(70,4 \%)$, серед яких удвічі більше від цукрового діабету, на 13,9\% від хвороб сечостатевої системи. Окремо зауважимо збільшення хвороб крові, кровотворних органів та сполучної тканини (на 83,3\%), а серед хвороб кровообігу на тлі зменшення показників стало більше інфарктів (17,8\%), цереброваскулярних уражень (2,4\%). Менші зміни за вказаний період спостерігались серед жителів міст - на 8,1\%; зріс показник смертності від злоякісних новоутворень та на 41,0\% - зовнішніх причин смерті, за рахунок чого вони увійшли до провідної тріади. При порівнянні рівнів смертності з провідних іï причин привертає увагу наступне: їх величини суттєво вищі в сільських поселеннях внаслідок хвороб кровообігу та зовнішніх причин, а в міських - внаслідок злоякісних новоутворень.

Статеві особливості також мають бути враховані. Вище зазначалось, що в регіоні частка по- мерлих жінок була вірогідно меншою, проте за рахунок повільнішого скорочення випадків вона збільшилась на 10\% і у 2012 р. перевищила по-



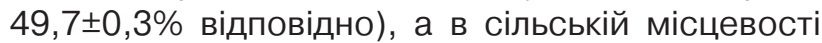

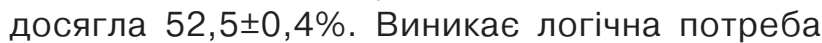
у з'ясуванні характеру змін причин втрати як чоловічого, так і жіночого населення області. 3 даних табл. 3 видно, що стабільно за частотою причин перші два місця належали хворобам системи кровообігу та злоякісним новоутворенням. Наступна послідовність не збігається в осіб чоловічої та жіночої статі. Серед жінок хвороби органів дихання переходять з третього місця на четверте, поступаючись хворобам органів травлення, на п'ятому перебувають зовнішні причини. Далі йдуть інфекційні, ендокринні, нервові, хвороби сечостатевої та кістково-м'язової систем, завершують перелік хвороби крові. Натомість у чоловіків зовнішні причини стоять на третьому місці, за ними йдуть хвороби органів травлення та дихання. Хвороби нервової системи також частіше, ніж ендокринні у жінок, призводять до смерті чоловіків. За рештою причин різниці не виявлено.

Таблиця 3. Динаміка причин смерті чоловічого та жіночого населення області (на 100 тис. відповідного населення)

\begin{tabular}{|c|c|c|c|c|c|c|}
\hline \multirow{2}{*}{ Основна причина смерті } & \multicolumn{3}{|c|}{ Чоловіки } & \multicolumn{3}{|c|}{ Жінки } \\
\hline & 2008 & 2012 & $\mathrm{~T} \pi / 3$ & 2008 & 2012 & $\mathrm{~T} \Pi / 3$ \\
\hline \multirow{2}{*}{$\begin{array}{l}\text { Інфекційні та паразитарні хвороби, } \\
\text { у т.ч. туберкульоз }\end{array}$} & 45,5 & 34,6 & $-23,9$ & 8,7 & 8,9 & $+2,3$ \\
\hline & 36,5 & 26,2 & $-28,2$ & 5,4 & 4,3 & $-20,4$ \\
\hline Злоякісні новоутворення & 187,7 & 211,4 & $+12,6$ & 128,8 & 138,1 & $+7,2$ \\
\hline Хвороби крові & 0,6 & 0,7 & $+16,7$ & 0,8 & 1,1 & $+37,5$ \\
\hline \multirow{2}{*}{$\begin{array}{l}\text { Ендокринні хвороби, } \\
\text { у т. ч. цукровий діабет }\end{array}$} & 7,7 & 7,1 & $-7,8$ & 8,5 & 8,6 & $+1,2$ \\
\hline & 7,2 & 6,4 & $-11,1$ & 7,9 & 7,7 & $-2,5$ \\
\hline Хвороби нервової системи & 12,5 & 9,7 & $-22,4$ & 7,8 & 4,1 & $-47,4$ \\
\hline \multirow{6}{*}{$\begin{array}{l}\text { Хвороби системи кровообігу } \\
\text { у т. ч. ГХ } \\
\text { інфаркт міокарда } \\
\text { ішемічна хвороба серця } \\
\text { інсульти } \\
\text { цереброваскулярні хвороби }\end{array}$} & 841,8 & 762,9 & $-9,4$ & 913,5 & 855,3 & $-6,4$ \\
\hline & 2,7 & 2,5 & $-7,4$ & 1,3 & 1,5 & $+15,4$ \\
\hline & 28,6 & 28,2 & $-1,4$ & 17,5 & 17,1 & $-2,3$ \\
\hline & 662,5 & 558,7 & $-15,7$ & 700,9 & 632,5 & $-9,7$ \\
\hline & 88,4 & 76,3 & $-13,7$ & 79,6 & 68,3 & $-14,2$ \\
\hline & 116,1 & 106,7 & $-8,1$ & 114,1 & 109,7 & $-3,8$ \\
\hline Хвороби органів дихання & 81,8 & 54,8 & $-33,0$ & 31,9 & 22,8 & $-28,5$ \\
\hline Хвороби органів травлення & 81,8 & 61,1 & $-25,3$ & 30,4 & 26,2 & $-13,8$ \\
\hline Хвороби кістково-м'язової системи & 1,8 & 0,9 & $-50,0$ & 2,5 & 1,5 & $-40,0$ \\
\hline Хвороби сечостатевої системи & 5,7 & 5,0 & $-12,3$ & 4,5 & 4,0 & $-11,1$ \\
\hline Зовнішні причини & 165,3 & 104,2 & $-37,0$ & 29,5 & 22,7 & $-23,0$ \\
\hline
\end{tabular}

Слід зазначити, що за винятком хвороб ендокринної системи, у тому числі цукрового діабету, хвороб кістково-м'язової системи та хвороб крові, рівні смертності чоловіків суттєво вищі, ніж жінок. Причому більші показники смертності жіночого населення з приводу хвороб кровообігу формують ішемічна хвороба серця та цереброваскулярна патологія.

Не викликає сумніву наявність повікових особливостей причин смерті і їх значення в системному підході до покращення ситуації. Вони проявляються в частоті тих чи інших, що призводять 
до смерті, патологій та значно вищими величинами їх показників, за винятком інфекцій та паразитарних хвороб, серед населення старше працездатного віку.

Основними причинами втрати осіб пенсійного віку є хвороби системи кровообігу, злоякісні новоутворення та хвороби органів дихання. Вони $€$ провідними за всі роки вивчення. Четверте місце з варіаціями за часом належить хворобам органів травлення або зовнішнім причинам (у 2012 р. першим з них). Наступна послідовність виглядає таким чином: ендокринні, інфекційні, хвороби сечостатевої та нервової, кістковом'язової систем та крові. У працездатному віці зміни стосувались лише другого місця. Після хвороб кровообігу його займали зовнішні причини, а у 2012 р. вони поступилися злоякісним новоутворенням. Така ситуація склалася за рахунок жителів міст, тоді як серед сільських залишались зовнішні причини. Зазначимо, що у чоловіків зовнішні причини превалюють, тому вони займають друге місце, яке у жінок належить злоякісним новоутворенням. Решта причин стабільно були розташовані в наступній послідовності: хвороби органів травлення, інфекційні, дихання, нервові, ендокринні, хвороби сечостатевої, кістково-м'язової систем та хвороби крові. Зауважимо, що така структура причин, за окремим винятком, близька до такої загалом по Україні. Різницю становлять восьме і дев'яте місця, коли дев'яте займають ендокринні хвороби, а не сечостатевої системи, як в регіоні. Треба вказати на факт інтенсивного зростання втрати населення післяпрацездатного віку з таких причин: інфекційні хвороби (18,5\%), зокрема туберкульоз (24,6\%), злоякісні новоутворення (1,4\%), гіпертонічна хвороба $(46,3 \%)$, інфаркт $(4,2 \%)$, хвороби органів травлення (19,2\%). Натомість серед осіб працездатного віку темп зростання до 7,5\% був притаманним лише злоякісним новоутворенням.

\section{Висновки}

1. У структурі померлих Львівської області в усі роки спостереження частка осіб працездатного віку чоловічої статі у чотири рази перевищує таку жіночої (у 2012 р. - 29,02\% та 6,67\% відповідно) з практично однаковим темпом зменшення; очікувано переважає доля осіб старше працездатного віку, де, навпаки, жінок у 1,3-1,5 разу більше, тоді як зростання випадків у 6 разів інтенсивніше серед чоловіків.

2. Структура причин втрати сільського та міського населення області збігалася за роки вивчення: перші три місця належали хворобам системи кровообігу, злоякісним новоутворенням, зовнішнім причинам; 6-11 місця посіли інфекційні, ендокринні, хвороби нервової, сечостатевої, кістково-м'язової систем та хвороби крові відповідно. Виняток становлять хвороби органів травлення та дихання: перші займають четверте місце, а п'яте - останні серед міських, тоді як у сільській місцевості - навпаки. Такий розподіл спостерігається й загалом по Україні, за винятком сьомого місця, яке в області посідають ендокринні хвороби, та восьмого, яке посіли хвороби нервової системи, а в країні вони змінюються за своєю послідовністю.

3. Виявлені відмінності причин смерті жінок та чоловіків. При збереженні хвороб кровообігу та злоякісних новоутворень на перших двох місцях наступними серед жінок були хвороби органів травлення, які перемістилися з четвертого, та органів дихання, на п'ятому - зовнішні причини, тоді як у чоловіків останні займали третє місце, а далі йшли хвороби органів травлення та дихання.

4. Рівні смерті серед чоловіків, за винятком хвороб кровообігу, ендокринних хвороб, кістковом'язової системи та хвороб крові, значно вищі, ніж серед жінок; серед хвороб кровообігу у жінок переважала IXC та цереброваскулярні, у чоловіків - інфаркт міокарда та інсульт. Крім того, зовнішні причини, хвороби нервової системи частіше призводять до втрати чоловіків, вони займають третє та сьоме місця, тоді як у жінок - хвороби органів травлення та ендокринні хвороби відповідно.

5. У осіб працездатного віку серед причин смерті друге місце, з часом замість зовнішніх причин, зайняли злоякісні новоутворення. Така ситуація склалася за рахунок жителів міст, тоді як серед сільських залишились зовнішні причини; переважали вони й серед осіб чоловічої статі, на відміну від яких у жінок переважали злоякісні новоутворення. Решта причин представлена в наступній послідовності: хвороби органів травлення, інфекційні, дихання, нервової системи, ендокринні, хвороби сечостатевої, кістковом'язової систем та хвороби крові. Подібний розподіл спостерігався й серед зазначеної когорти в цілому по Україні, де лише на 9 місці хвороби сечостатевої системи змінилися на ендокринні.

Перспективи подальших досліджень пов'язані з розробкою комплексних міжсекторальних заходів зниження смертності населення.

\section{Список літератури}

1. Охорона здоров'я України: стан, проблеми, перспективи / Лазоришинець В. В., Лісневська Н. О., Ковальчук Л. Я. [та ін.]. - К., 2014. - 608 с.

2. Про порядок проведення реформування системи охорони здоров'я у Вінницькій, Дніпропетровській, Донецькій областях та місті Києві : Закон України від 07.07.2011 № 3612-VI // Відомості Верховної Ради України. - 2012. - № 12 (№ 12-13). - С. 552. 
3. Слабкий Г. О. Регіональні особливості стану здоров'я населення України / Г. О. Слабкий, Н. В. Медведовська. - К., 2010. - 174 c.

4. Сучасні та прогнозні тенденції смертності населення України : монографія / Г. О. Слабкий, О. М. Орда, Л. А. Чепелевська, О. В. Любінець. - К., 2010. - 179 с.

5. Щорічна доповідь про стан здоров'я населення, санітарно-епідемічну ситуацію та результати діяльності системи охорони здоров'я України. 2013 рік / за ред. О. С. Мусія. - К., 2014.- 438 с.

\section{ОБЩИЕ ОСОБЕННОСТИ ДИНАМИКИ ПРИЧИН СМЕРТИ СРЕДИ РАЗНЫХ СЛОЕВ ВЗРОСЛОГО НАСЕЛЕНИЯ ЛЬВОВСКОЙ ОБЛАСТИ}

Ю.Б. Ященко ${ }^{1}$, А.А. Семенюк', Я.Л. Гржибовский

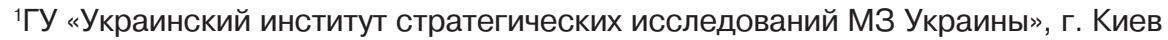

2Львовский национальный медицинский университет им. Данила Галицкого, Украина

Цель: проанализировать утраты взрослого населения Львовской области.

Материалы и методы. В ходе исследования использовались библиосемантический и статистический методы. Первичным материалом были данные официальной статистики - формы статистического учета за период 2008-2012 годов.

Результаты. В структуре умерших Львовской области за все годы наблюдения доля лиц трудоспособного возраста мужского пола в четыре раза превышает такую женской с практически одинаковым темпом уменьшения; ожидаемо превалирует доля лиц старше трудоспособного возраста. Структура причин смерти сельского и городского населения области совпадала за годы изучения: первые три места принадлежали болезням системы кровообращения, злокачественным образованиям, внешним причинам. Основными причинами потерь лиц пенсионного возраста за все годы изучения являются болезни системы кровообращения, злокачественные новообразования и болезни органов дыхания.

Выводы. Установлены отличия в уровнях и причинах смертности разных категорий населения нужно учитывать при разработке комплексных мер снижения смертности населения.

КЛЮЧЕВЫЕ СЛОВА: смертность взрослого населения, динамика, причины.

\section{GENERAL DYNAMICS FEATURES OF DEATH CAUSE AMONG VARIOUS SEGMENTS OF ADULT POPULATION OF LVIV REGION}

J.B. Yashchenko', O.A. Semenyuk', Ya.L. Hrzhybovskyi

${ }^{1} \mathrm{PE}$ "Ukrainian Institute of Strategic Researches MHC of Ukraine", Kyiv

${ }^{2}$ Lviv National Medical University named after Danylo Galytskyi, Ukraine

Purpose: to analyze losses of adult population of Lviv region.

Materials and methods. Under research bibliosemantyck and statistical methods are used. The primary material were the data of official statistics - forms of statistical records for the period 2008-2012.

Results. In structure of the dead in Lviv region in all years of supervision share of working-age male four times exceeds those female with practically identical rate of reduction; it is expected predominant share of people more senior than working age. The structure of the death causes of rural and urban population of the region coincided during years of studying: first three places belonged to cardiovascular diseases, malignant neoplasms, external causes. The main reasons of loss of persons of pension age for all years of studying are cardiovascular diseases, malignant neoplasms and respiratory diseases.

Conclusions. The established distinctions in levels and death causes of various categories of the population should be taken into account by development of comprehensive measures of reduction mortality of the population.

KEY WORDS: mortality of adult population, dynamics, reasons.

Рукопис надійшов до редакції 07.11.2014 р.

\section{Відомості про авторів:}

Ященко Юрій Борисович - д.мед.н., проф., ДУ «Український інститут стратегічних досліджень МОЗ України»; тел.:+38 (044) 576-41-19.

Семенюк Олександр Андрійович - лікар-стоматолог-терапевт, Інститут стоматології НАПО ім. П.Л. Шупика, пошукач ДУ «Український інститут стратегічних досліджень МОЗ України»; тел.:+38 (044) 576-41-19.

Гржибовський Ярослав Леонідович - асистент кафедри організації і управління охороною здоров'я Львівського національного медичного університету імені Данила Галицького; тел.: +38 (032) 275-76-32. 